\title{
Assessment of radiological hazards from soil samples in the Northeastern area of Burkina Faso
}

\author{
Cedric E. Beogo ${ }^{1,3}$ (D) Ousmane I. Cisse $\mathrm{C}^{2,3} \cdot$ Francois Zougmore ${ }^{2,3}$
}

Received: 28 October 2021 / Accepted: 19 January 2022

Published online: 05 February 2022

(c) The Author(s) 2022 OPEN

\begin{abstract}
The activity concentrations of main naturally occurring radionuclides were determined with the aim of assessing the radiation hazards in the Northeastern part of Burkina Faso. Soil samples were taken and analyzed by the gamma-ray spectrometry method. The ranges of specific activity of ${ }^{238} \mathrm{U},{ }^{232} \mathrm{Th}$ and ${ }^{40} \mathrm{~K}$ are $15.25 \pm 2.59 \mathrm{~Bq} \cdot \mathrm{kg}^{-1}$ to $109.57 \pm 3.21 \mathrm{~Bq} \cdot \mathrm{kg}^{-1}$, $19.56 \pm 1.65 \mathrm{~Bq} \cdot \mathrm{kg}^{-1}$ to $44.88 \pm 2.49 \mathrm{~Bq} \cdot \mathrm{kg}^{-1}$ and $125.74 \pm 4.40 \mathrm{~Bq} \cdot \mathrm{kg}^{-1}$ to $705.85 \pm 10.79 \mathrm{~Bq} \cdot \mathrm{kg}^{-1}$ respectively. Three high background radioactivity areas have been identified for Uranium, Thorium and Potassium on different places in the study area. The radiological hazards indices vary from $62.87 \mathrm{~Bq} \cdot \mathrm{kg}^{-1}$ to $189.47 \mathrm{~Bq} \cdot \mathrm{kg}^{-1}$ for the Radium equivalent activity $\left(R a_{e q}\right), 29.5 \eta \mathrm{Gy} \cdot \mathrm{h}^{-1}$ to $86.65 \eta \mathrm{Gy} \cdot \mathrm{h}^{-1}$ for the absorbed dose rate $\left(D_{R}\right), 0.18 \mathrm{mSv} \cdot \mathrm{y}^{-1}$ to $0.53 \mathrm{mSv} \cdot \mathrm{y}^{-1}$ for the annual effective dose rate (AEDE), 0.21 to 0.81 for the internal hazard index $\left(H_{i n}\right), 0.17$ to 0.51 for the external hazard index $\left(H_{e x}\right)$, $1.27 \times 10^{-4}$ to $3.73 \times 10^{-4}$ for the Excess Lifetime Cancer Risk (ELCR) and $209.01 \mu 0.18 \mathrm{~Sv} \cdot \mathrm{y}^{-1}$ to $594.21 \mu \mathrm{Sv} \cdot \mathrm{y}^{-1}$ for the annual gonadal dose equivalent. The average values of indices are well below their permissible limit. However, at Niapsi the obtained values for absorbed dose rate, annual effective dose rate and excess lifetime cancer risk are little above their permissible limit.
\end{abstract}

Keywords Radiological anomaly · Soil samples · Natural radioactivity · Gamma-ray spectrometry

\section{Introduction}

Radioactivity is a natural phenomenon manifested by the emission of ionizing radiations. These radiations are imperceptible by human senses and can only be detected by special devices. Radioactivity is omnipresent and it is found everywhere in different concentrations levels in the environment, drinking water, foodstuffs, air, soil and even inside the human body. When the radioactivity level is high enough, it can induce harmful effects on human health. The main elements responsible for radioactivity are essentially ${ }^{238} \mathrm{U},{ }^{235} \mathrm{U},{ }^{232}$ Th and ${ }^{40} \mathrm{~K}$. These terrestrial radionuclides have been there since the formation of Earth, 4.5 billion years ago. They are unevenly distributed in space, depending on the geological nature of the soil and they are the main source of exposition of human body to ionizing radiation. There are two kinds of exposure to ionizing radiation: external exposure and internal exposure. External exposure is manifested by the interaction of gamma, alpha or beta radiation emitted by a radionuclide with the human body. The gammaray radiation is very dangerous and difficult to stop. For this, several centimeters of lead or

Ousmane I. Cisse andFrancois Zougmore have contributed equally to this work.

$\triangle$ Cedric E. Beogo, cedricbeogo@yahoo.fr; Ousmane I. Cisse, oicisse@yahoo.fr; Francois Zougmore, fr.zougmore@laposte.net |'Thomas SANKARA University, Saaba, Ouagadougou 12 BP 417, Kadiogo, Burkina Faso. ${ }^{2}$ Department of Physics, Joseph KI-ZERBO University, Avenue Joseph KI-ZERBO, Ouagadougou 03 BP 7021, Kadiogo, Burkina Faso. ${ }^{3}$ Laboratory of Materials and Environment (LAME), Joseph KI-ZERBO University, Avenue Joseph KI-ZERBO, Ouagadougou 03 BP 7021, Kadiogo, Burkina Faso.

SN Applied Sciences $\quad$ (2022) 4:73 $\quad$ https://doi.org/10.1007/s42452-022-04960-x 
several meters of concrete are needed to absorb it. Alpha radiation is also harmful to health but, fortunately, it has a very low penetrating power and can be stopped with a simple sheet of paper or a few centimeters of air. The beta radiation is quite penetrating and one need several meters of air or a few millimeters of aluminum to stop it. The internal exposure occurs when the subject incorporates by inhalation or by ingestion a radionuclide which decays inside the organism. Radioactivity could be harmful for human health and there are some places where the radioactivity is significantly higher than normal areas. In Burkina Faso, an airborne study revealed the presence of uranium anomalies in the Northeastern part of the country [1]. The airborne study was carried out at a given altitude above the ground and, it has not been possible to determine whether the anomaly presented radiological risks or not. In this part of the country, gold mining activities which lead to the release of soil dust from pits, are widely practiced. It would be important to perform studies in order to know the radiological impact of these activities, on the health of the populations. In order to bring some precisions on the anomaly, radioactivity has been measured on the ground through soil samples. In the present study, the concentration of main naturally occurring radionuclides is determined and the radiation hazards associated with the presence of these radionuclides is assessed.

\section{Materials and methods}

\subsection{Study area}

The present study was performed in the NorthEastern part of Burkina Faso. Samples have been taken in the villages of Tangarce, Soula, Pougbonne and Koulfou located in the north part of Gnagna in Bogande ( $N 13.00242^{\circ}$, $W 0.13644^{\circ}$ ) and the villages of Niapsi (located in Solhan) and Gourgnel located in Sebba ( $\left.N 13.43669^{\circ}, E 0.53598^{\circ}\right)$. The climate is Sudano-Sahelian and composed of two seasons: A dry season which runs from November to May and a rainy season from June to October. The dry season is characterized by a cold period from December to February accompanied by a dry wind (Harmattan) which takes place in the Sahara. The dry season is dominated by heat which starts in March. During this season, extreme temperatures are reached $\left(45^{\circ} \mathrm{C}\right.$ in April and $15^{\circ} \mathrm{C}$ in January). In addition, the average falling rainwater during the rainy season is from 500 to $800 \mathrm{~mm}$.

Previously, studies have been performed in the study area, in order to highlight the uranium anomalies first and then, to determine the gamma dose rate level at one meter above the ground for various depths by using IdentiFinder device $[2,3]$. These works allowed to identify some relatively high background radioactivity points where it has been recommended to perform radioanalytical investigations. For more precision and in order to know the nature and amount of radionuclides responsible of these anomalies, the present study is undertaken, and soil samples have been taken to the laboratory for analysing by the gamma-ray spectrometry method $[4,5]$.

\subsection{Sample collection and preparation}

The identiFINDER R-400 (model idF2-ULK-NGH) provided with a room temperature detector of sodium iodide ( $\mathrm{Nal}$ ), is used to get an estimation of the radioactivity level in the study area. Then, sample has been collected from some geographic points where radioactivity is relatively high by digging the ground with a manual core drill (collector) fitted with three compartments which must be screwed together before using: A first compartment of the collector is an approximately twenty (20) centimeters high cylinder. The base of this cylinder has been cut to obtain interlocking hooks allowing it to easily sink into the ground following an applied rotation and to be able to carry the soil between the teeth of the hooks. A second compartment is a rod attached to the top of the first compartment. It connects the sample collector to the sleeve. A third compartment is a sleeve connected to the rod. A physical manual force applied to this part of the collector induce a rotation of the cylinder which lead to the extraction of soil sample.

In the study area, the identiFINDER R-400 is turned on to look for a relatively high background coordinate points where gamma dose rate is higher than $100 \mu \mathrm{Sv} \cdot \mathrm{h}^{-1}$. Once a point is located, sampling points are randomly chosen around this point and its GPS (model Garmin eTrex 10) coordinates are noted first then, after having assembled the various compartments of the collector, a stratum of soil is taken at the depth of up to $20 \mathrm{~cm}$ of the ground [3]. Ten (10) soil samples were taken and analyzed by gammaray spectrometry respectively from the localities of Soula, Tangarce, Pougbonne, Koulfou, Niapsi and Gourgnel (see figure 1). Samples were put in a plastic bags which were stapled with a piece of coded paper and then, an associated sample collection form is filled. Collected samples have been prepared from April to June of 2019. The dried samples have been sieved, weighted and put inside $100 \mathrm{~cm}^{3}$ bottle for at least four (04) weeks to reach the secular equilibrium of ${ }^{238} \mathrm{U}$ and ${ }^{232} \mathrm{Th}$ with their respective daughter progenies.

\subsection{Radioactivity measurement}

A High Purity Germanium (HPGe) detector model (GC4010) based gamma-ray spectrometer was employed 
Fig. 1 Study area and sample locations

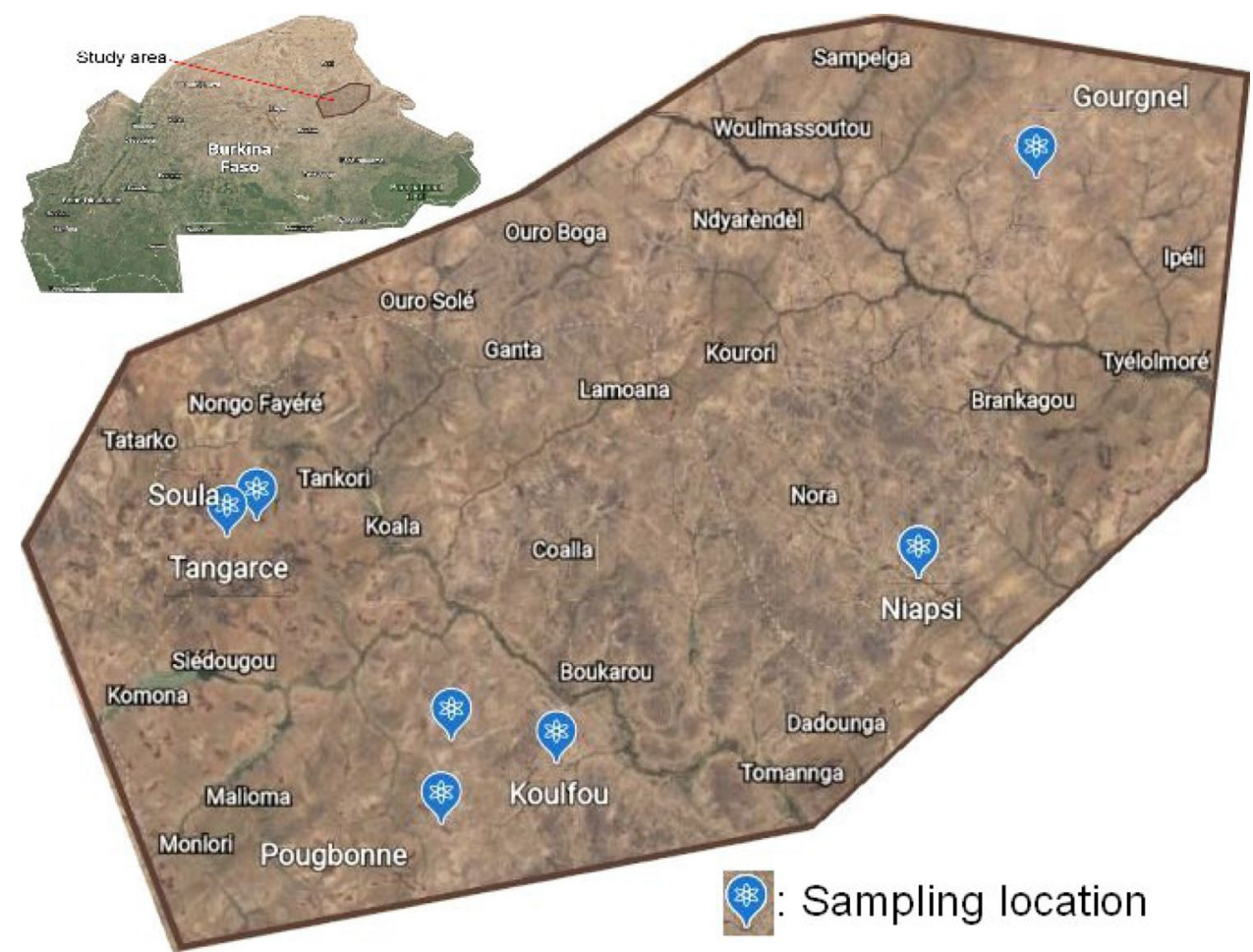

for samples analysis. The resolution of the spectrometry system was $1.8 \mathrm{KeV}$ at $1330 \mathrm{KeV}$ gamma-ray line of ${ }^{60} \mathrm{Co}$ and $0.875 \mathrm{KeV}$ at $122 \mathrm{KeV}$ energy line. This model of detector is a coaxial one of $60.9 \mathrm{~mm}$ diameter and 63.3 $\mathrm{mm}$ height, equiped with a hybrid cooling system by a compressor that condenses nitrogen. In addition to the detector, the system consists of a preamplifier, an analog to digital converter (ADC), a multi-channel analyzer (MCA) consisting of 8192 channels and a display screen.

In order to provide accurate analysis of results, the spectrometer system was adequately calibrated in energy, resolution and efficiency. A spectrum is aquired for $216000 \mathrm{~s}$ each week to get the background which will be substracted by sample spectrum. The sample is placed on the detector for 24 hours for spectrum acquisition. There are basically two methods for measuring radioactivity by gamma spectrometry. The direct method, which exploits the gamma radiation emitted by the deexcitation of the radioactive nuclei one to analyze. However, not all nuclei emit gamma radiation. This is the case for example with ${ }^{232} \mathrm{Th}$ and ${ }^{238} \mathrm{U}$. For this, we have recourse to the indirect method which consists in exploiting the secular balance between these nuclei and their descendants. Thus, to determine the activity of ${ }^{238} \mathrm{U}$, we considered, in its progeny, radionuclides such as ${ }^{234} \mathrm{Th}$ (with gammaray energy lines of $63.30 \mathrm{KeV}, 92.38 \mathrm{KeV}$ and $92.80 \mathrm{KeV}$ ), ${ }^{214} \mathrm{~Pb}$ (with gammaray energy lines of $242 \mathrm{KeV}, 295.22 \mathrm{KeV}$ and $351.93 \mathrm{KeV}$ ) and ${ }^{214} \mathrm{Bi}$ (with gammaray energy lines of $609.31 \mathrm{KeV}, 1120.29 \mathrm{KeV}$ and 1764.49
$\mathrm{keV}$ ). For the ${ }^{232} \mathrm{Th}$, we used the radionuclides ${ }^{212} \mathrm{~Pb}$ (with gammaray energy lines of $238.63 \mathrm{KeV}$ and $300.09 \mathrm{KeV}$ ), ${ }^{212} \mathrm{Bi}$ (with gammaray energy line of $727.33 \mathrm{keV}$ ) and ${ }^{228} \mathrm{AC}$ (with gammaray energy lines of $338.32 \mathrm{KeV}, 911.20 \mathrm{KeV}$, $968.96 \mathrm{KeV}$ ). The determination of the activity of ${ }^{40} \mathrm{~K}$ is direct, using the gammaray energy line of $1460.83 \mathrm{KeV}$.

The efficiency of the analysis procedure was tested with a quality control sample. This is the sample3 (IAEATEL-2019-03) provided by the International Atomic Energy Agency for the proficiency test. The results obtained are presented in Table 1. A good approximation is obtained between the measured values and the target values. The minimum detectable activity (MDA) of the radionuclides ${ }^{238} \mathrm{U},{ }^{232} \mathrm{Th}$ and ${ }^{40} \mathrm{~K}$ is calculated and is $3.77 \mathrm{~Bq} \cdot \mathrm{Kg}^{-1}, 5.35 \mathrm{~Bq} \cdot \mathrm{Kg}^{-1}$ and $9.37 \mathrm{~Bq} \cdot \mathrm{Kg}^{-1}$ respectively.

Table 1 Activity concentrations in the Quality Control material of IAEA Terrestral Environment Laboratory (2019-03)

\begin{tabular}{llllll}
\hline Nuclides & \multicolumn{2}{l}{ Measured values } & & \multicolumn{2}{l}{ Target values } \\
\cline { 2 - 3 } \cline { 5 - 6 } & $A_{e}\left(\mathrm{~Bq} \cdot \mathrm{Kg}^{-1}\right)$ & unc.(1s $)$ & & $A_{e}\left(\mathrm{~Bq} \cdot \mathrm{Kg}^{-1}\right)$ & unc.(1s) \\
\hline Mn54 & 13.89 & 0.34 & & 13.8 & 0.4 \\
Cs134 & 4.94 & 0.87 & & 5.03 & 0.05 \\
Cs137 & 26.27 & 0.56 & & 27.6 & 0.2 \\
Ra226 & 5.89 & 6.90 & & 9.10 & 0.30 \\
\hline
\end{tabular}




\subsection{Radiological hazard calculation}

\subsubsection{Radium equivalent $\left(R a_{e q}\right)$}

The Radium equivalent $\left(R a_{e q}\right)$ activity is a radiological risk index that is used to assess the harmful effects of ionizing radiation on health. This index is associated to the internal and external exposure due to radon and its daughter progenies. The expression of $R a_{e q}$ is obtained by assuming that $370 \mathrm{~Bq} \cdot \mathrm{Kg}^{-1}$ of ${ }^{238} \mathrm{U}, 259 \mathrm{~Bq} \cdot \mathrm{Kg}^{-1}$ of ${ }^{232} \mathrm{Th}$ and $4810 \mathrm{~Bq} \cdot \mathrm{Kg}^{-1}$ of ${ }^{40} \mathrm{~K}$ produce equal gamma dose. The Radium equivalent activity is mathematically defined by [6]:

$R a_{e q}\left(\mathrm{~Bq} \cdot \mathrm{Kg}^{-1}\right)=A_{U}+1.43 A_{T h}+0.077 A_{K}$

Where $A_{U}, A_{T h}$ and $A_{K}$ are the specific activity concentration of ${ }^{238} \mathrm{U},{ }^{232} \mathrm{Th}$ and ${ }^{40} \mathrm{~K}$ respectively. The recommended maximum limit value of $R a_{e q}$ activity is $370 \mathrm{~Bq} \cdot \mathrm{Kg}^{-1}$.

\subsubsection{Absorbed dose $\left(D_{R}\right)$}

The gamma dose rate is a measure of the gamma radiation energy released by radionuclides per unit time and unit mass of exposed material. It is expressed in Gray per hour $\left(G y \cdot h^{-1}\right)$ and represents the level of a body exposure to an external source of radiation. The absorbed dose at one meter $(1 \mathrm{~m})$ above the ground, due to a radionuclide, can be determined by the specific activity of this radionuclide. Theoretical calculations have allowed to establish relation between specific activity and gamma dose rate which expression is given by the following formula [6]:

$D_{R}\left(\eta \mathrm{Gy} \cdot \mathrm{h}^{-1}\right)=0.462 A_{U}+0.604 A_{T h}+0.042 A_{K}$

\subsubsection{Annual effective dose equivalent (AEDE)}

The annual effective dose equivalent is the amount energy of gamma radiation released by a radioactive source which takes into account the radio-sensitivity of different organs of the human body. It is expressed by the following relation [6]:

$\operatorname{AEDE}\left(\mathrm{mSv} \cdot \mathrm{y}^{-1}\right)=D_{R}\left(\eta \mathrm{Gy} \cdot \mathrm{h}^{-1}\right) \times 0.00123$

\subsubsection{Annual gonadal dose equivalent (AGDE)}

The annual gonadal dose equivalent gives an estimation of the annual equivalent dose received in the gonads (reproductive organ). The AGDE for an exposition to natural source of radioactivity is given by the following formula [6]:

$\operatorname{AGDE}\left(\mu \mathrm{Sv} \cdot \mathrm{y}^{-1}\right)=3.09 A_{U}+4.18 A_{T h}+0.314 A_{K}$

\subsubsection{Radiation hazard index}

External hazard index $\left(H_{e x}\right)$ The external hazard index is a parameter used to evaluate the radiological risks of materials due to an external exposure to gamma radiation. The recommended value of $H_{e x}$ must be less than $1 \mathrm{mSv} \cdot \mathrm{y}^{-1}$ and its expression is given by the following relation [6]:

$H_{e x}=\frac{A_{U}}{370 \mathrm{~Bq} \cdot \mathrm{Kg}^{-1}}+\frac{A_{T h}}{259 \mathrm{~Bq} \cdot \mathrm{Kg}^{-1}}+\frac{A_{K}}{4810 \mathrm{~Bq} \cdot \mathrm{Kg}^{-1}}$

Internal hazard index $\left(H_{i n}\right)$ The internal hazard index is a parameter used to assess the risks associated with the presence of natural radionuclides in building materials due to an internal exposure to radon $\left({ }^{222} R n\right)$ and its daughter progenies by inhalation of alpha particles. Its expression is given by the following formula :

$H_{\text {in }}=\frac{A_{U}}{185 \mathrm{~Bq} \cdot \mathrm{Kg}^{-1}}+\frac{A_{T h}}{259 \mathrm{~Bq} \cdot \mathrm{Kg}^{-1}}+\frac{A_{K}}{4810 \mathrm{~Bq} \cdot \mathrm{Kg}^{-1}}$

\subsubsection{Excess lifetime cancer risk (ELCR)}

The carcinogenic effects of gamma radiation due to ingestion, inhalation and external exposure to a radioactive sources are characterized by an estimation of cancer occurring probability during a specific lifetime. This probability is determined by the calculation of the excess lifetime cancer risk (ELCR). Its expression is given by the following relation [7]:

$E L C R=A E D E \times D L \times R F$

In this expression, $D L$ is the duration of life (70 years) and $R F$ is the risk factor for cancer considering the stochastic effects. $R F$ is equal to $0.05 \mathrm{~Sv}^{-1}$ for the public [7].

\section{Results and discussions}

\subsection{Spatial distribution}

The activity concentration of ${ }^{238} \mathrm{U},{ }^{232} \mathrm{Th}$ et ${ }^{40} \mathrm{~K}$ were measured by gamma-ray spectrometry method for various soil samples collected at the depth of up to $20 \mathrm{~cm}$ in the Northeastern area of Burkina Faso. The specific activity values and their respective standard deviations (SD) of the above natural radionuclides 
Distribution of U-238

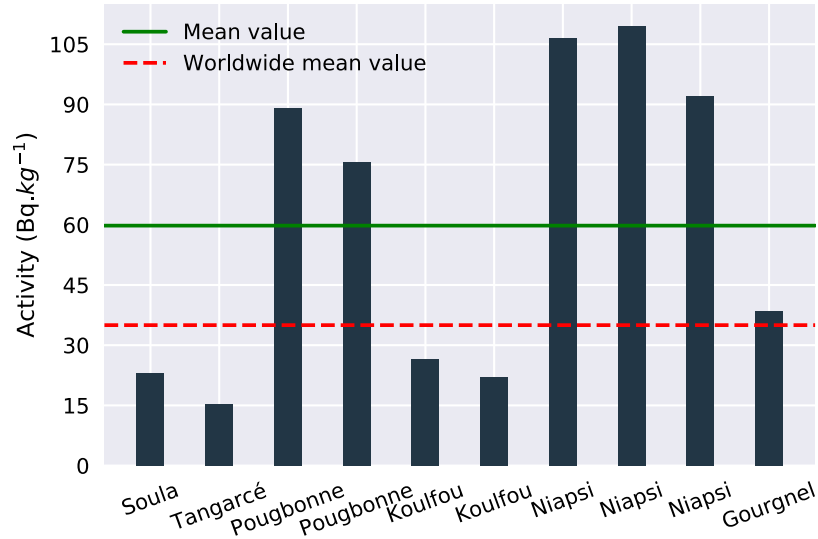

Distribution of K-40

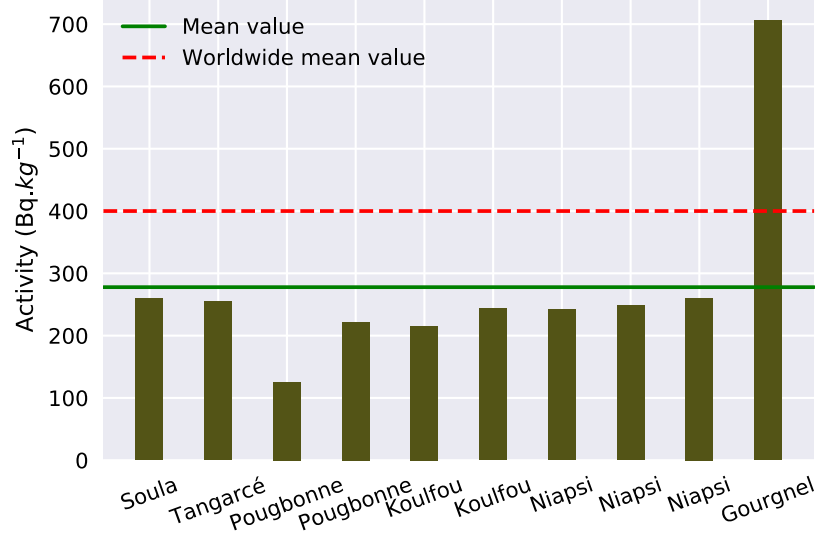

Distribution of Th-232

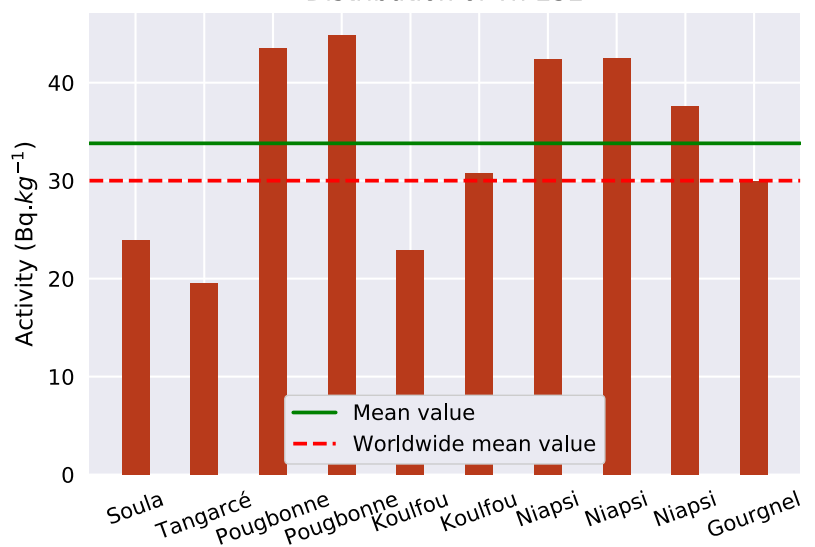

Contribution of U-Th-K

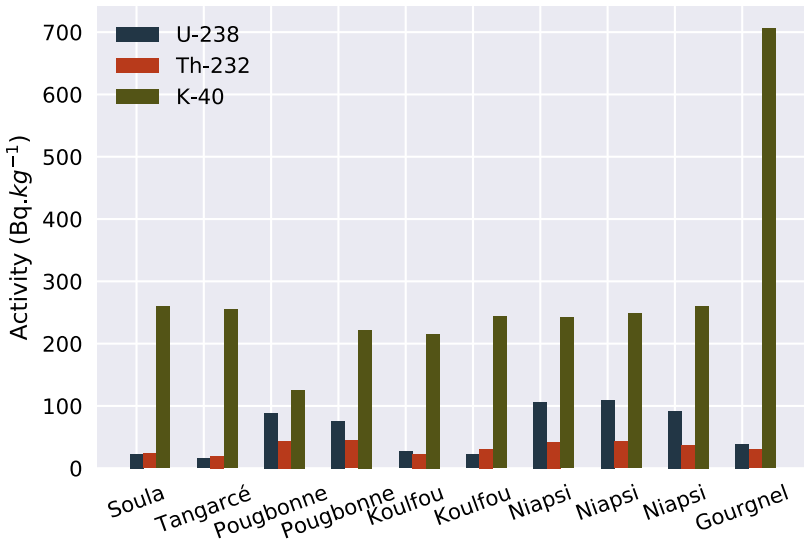

Fig. 2 Distribution of ${ }^{238} \mathrm{U},{ }^{232} \mathrm{Th}$ and ${ }^{40} \mathrm{~K}$ activity concentrations for a depth of $20 \mathrm{~cm}$

Table 2 Specific activity concentration of ${ }^{238} \mathrm{U},{ }^{232} \mathrm{Th}$ and ${ }^{40} \mathrm{~K}$ in soil samples from Northeastern Burkina Faso

\begin{tabular}{llllllll}
\hline Sample ID & Location & Depth $(\mathrm{cm})$ & \multicolumn{2}{l}{ Activity concentration $\mathrm{Bq} \cdot \mathrm{Kg}^{-1}( \pm S D)$} & U/Th & U/K \\
\cline { 5 - 6 } & & & U-238 & Th-232 & $\mathrm{K}-40$ & \\
\hline NE1101 & Soula & 20 & $23.00 \pm 2.41$ & $23.97 \pm 1.72$ & $259.33 \pm 6.11$ & 0.96 & 0.09 \\
NE2001 & Tangarce & $0-20$ & $15.25 \pm 2.59$ & $19.56 \pm 1.65$ & $255.19 \pm 6.20$ & 0.78 & 0.06 \\
NEX0201 & Pougbonne & $0-20$ & $88.98 \pm 3.80$ & $43.48 \pm 2.31$ & $125.74 \pm 4.40$ & 2.05 & 0.71 \\
NEX0301 & Pougbonne & $0-20$ & $75.54 \pm 3.62$ & $44.88 \pm 2.49$ & $221.61 \pm 5.75$ & 1.68 & 0.34 \\
NEX0501 & Koulfou & $0-20$ & $26.56 \pm 2.20$ & $22.91 \pm 1.37$ & $215.72 \pm 4.45$ & 1.16 & 0.12 \\
NEX0601 & Koulfou & $0-20$ & $21.93 \pm 2.11$ & $30.76 \pm 1.56$ & $243.96 \pm 4.90$ & 0.71 & 0.09 \\
NEX0901 & Niapsi & $0-20$ & $106.58 \pm 3.24$ & $42.45 \pm 2.07$ & $241.83 \pm 5.03$ & 2.51 & 0.44 \\
NEX1001 & Niapsi & $0-20$ & $109.57 \pm 3.21$ & $42.49 \pm 1.80$ & $248.52 \pm 4.99$ & 2.58 & 0.44 \\
NEX1101 & Niapsi & $0-20$ & $92.04 \pm 3.52$ & $37.66 \pm 2.02$ & $260.35 \pm 5.14$ & 2.44 & 0.35 \\
NEX1201 & Gourgnel & $0-20$ & $38.59 \pm 2.26$ & $29.98 \pm 1.70$ & $705.85 \pm 10.79$ & 1.29 & 0.05 \\
Mean value & Study area & $0-20$ & $59.80 \pm 2.90$ & $33.81 \pm 1.87$ & $277.81 \pm 5.77$ & 1.77 & 0.22 \\
\hline
\end{tabular}

obtained are presented in Table 2. Figure 2 shows the spatial representation of these radionuclides in the study area. The activity concentration of ${ }^{238} \mathrm{U}$ in the study area ranged from $15.25 \pm 2.59 \mathrm{~Bq} \cdot \mathrm{Kg}^{-1}$ at Tangarce village, to $109.57 \pm 3.21 \mathrm{~Bq} \cdot \mathrm{Kg}^{-1}$ for Niapsi soil sample with a mean value of $59.80 \pm 2.90 \mathrm{~Bq} \cdot \mathrm{Kg}^{-1}$. This value is higher than the world average of Uranium- 238 concentration of $35 \mathrm{~Bq} \cdot \mathrm{Kg}^{-1}$ (see Fig. 2). This is due to the contribution of localities like Pougbonne 
and Niapsi. In the locality of Niapsi, the ${ }^{238} \mathrm{U}$ concentration is three times higher than that of the world average. ${ }^{232}$ Th activity concentration ranged from $19.56 \pm 1.65 \mathrm{~Bq} \cdot \mathrm{Kg}^{-1}$ to $44.88 \pm 2.49 \mathrm{~Bq} \cdot \mathrm{Kg}^{-1}$ and the mean value is $33.81 \pm 1.87 \mathrm{~Bq} \cdot \mathrm{Kg}^{-1}$. This value is a little higher than the world average value of $30 \mathrm{~Bq} \cdot \mathrm{Kg}^{-1}$ (see Fig. 2). The ${ }^{40} \mathrm{~K}$ activity concentration ranged from $125.74 \pm 4.40 \mathrm{~Bq} \cdot \mathrm{Kg}^{-1}$ for Pougbonne village soil sample, to $705.85 \pm 10.79 \mathrm{~Bq} \cdot \mathrm{Kg}^{-1}$ for Gourgnel soil sample and the mean value was about $277.81 \pm 5.77 \mathrm{~Bq} \cdot \mathrm{Kg}^{-1}$. This value is well below the world average of $400 \mathrm{~Bq} \cdot \mathrm{Kg}^{-1}$. For each sample, the proportionality ratio between concentrations of ${ }^{238} \mathrm{U}$ and ${ }^{232} \mathrm{Th}(\mathrm{U} / \mathrm{Th}),{ }^{238} \mathrm{U}$ and ${ }^{40} \mathrm{~K}(\mathrm{U} / \mathrm{K})$ was calculated. The mean value of the U/Th is clearly higher than one (01) while that of the $U / K$ is clearly lower than one (01). This means that in most of the samples, ${ }^{238} \mathrm{U}$ concentration is higher than that of ${ }^{232} \mathrm{Th}$ but lower than that of ${ }^{40} \mathrm{~K}$. The activity concentration of ${ }^{238} \mathrm{U}$ is two times higher than that of the ${ }^{232} \mathrm{Th}$ at Niapsi village and the activity concentration of ${ }^{40} \mathrm{~K}$ worth twenty (20) times that of the ${ }^{238} \mathrm{U}$ at Gourgnel village (see Table 2).

The results presented show that the maximum concentration of ${ }^{238} \mathrm{U}$ measured at Niapsi is three times higher than that of the world average. It is greater than seven times the minimum concentration measured at Tangarce. The maximum ${ }^{232} \mathrm{Th}$ concentration measured at Niapsi is twice that of Tangarce and the ${ }^{40} \mathrm{~K}$ concentration at Niapsi is slightly lower than that obtained at Tangarce. In the study conducted by [2], the gamma dose rate measured at Tangarce was equal to the world average of $0.050 \mu \mathrm{Sv} \cdot \mathrm{h}^{-1}$ and its maximum value measured at Niapsi was $0.300 \mu \mathrm{Sv} \cdot \mathrm{h}^{-1}$, which is six times that of Tangarce. This ratio is comparable to that of the uranium concentrations. We can deduce that the radiological anomaly of the Niapsi locality is an uranium one. The high dose of radioactivity measured in this locality is mainly due to the presence of ${ }^{238} \mathrm{U}$. The maximum ${ }^{232} \mathrm{Th}$ concentration has been measured at Pougbonne and it is twice that of the minimum concentration obtained at Tangarce. The ${ }^{238} \mathrm{U}$ concentration of Pougbonne is worth five times that of Tangarce while the ${ }^{40} \mathrm{~K}$ concentration of Pougbonne is slightly lower than that of Tangarce. The gamma dose rate measured at Pougbonne is three times the gamma dose rate measured at Tangarce. It is true that in this situation, the ${ }^{238} \mathrm{U}$ concentration of the locality is quite high compared to Tangarce but ${ }^{232} \mathrm{Th}$ concentration ratio is comparable to that of the gamma dose rates of these two localities. We can therefore say that the anomaly observed at Pougbonne is mainly due to ${ }^{232} \mathrm{Th}$. The maximum ${ }^{40} \mathrm{~K}$ concentration has been measured at Gourgnel and it is 2.76 times that of the concentration obtained at Tangarce. The gamma dose rate measured at Gourgnel is approximately 2.6 times that obtained at Tangarce. This similarity of proportions allows us to affirm that the anomaly observed at Gourgnel is mainly due to the presence of ${ }^{40} \mathrm{~K}$. The main natural radionuclides have been identified and quantified. The results show a predominance of ${ }^{238} \mathrm{U},{ }^{232} \mathrm{Th}$ and ${ }^{40} \mathrm{~K}$ respectively in the localities of Niapsi, Pougbonne and Gourgnel. These results are important because they will make it possible not only to be able to orient research within the framework of a mining exploration activity but also to assess the radiological risks on human health. The village of Gourgnel is particularly rich in ${ }^{40} \mathrm{~K}$ and this could reflect the soil fertility of this locality. A comparison of the results with values reported worldwide from various sample collection depths, presented in Table 3, shows that ${ }^{238} \mathrm{U}$ activities concentration in the study area is higher than those reported by [8-16] and
Table 3 Activity concentration of ${ }^{238} \mathrm{U},{ }^{232} \mathrm{Th}$ and ${ }^{40} \mathrm{~K}$ measured worldwide

\begin{tabular}{|c|c|c|c|c|c|c|c|}
\hline \multirow[t]{2}{*}{ Locality/Country } & \multirow[t]{2}{*}{ Depth $(\mathrm{cm})$} & \multicolumn{3}{|c|}{$\begin{array}{l}\text { Activity concentra- } \\
\text { tion }\left(\mathrm{Bq} \cdot \mathrm{Kg}^{-1}\right)\end{array}$} & \multirow[t]{2}{*}{$\mathrm{U} / \mathrm{Th}$} & \multirow[t]{2}{*}{$\mathrm{U} / \mathrm{K}$} & \multirow[t]{2}{*}{ Reference } \\
\hline & & $\mathrm{U}-238$ & Th-232 & $\mathrm{K}-40$ & & & \\
\hline Tamilnadu(Inde) & $0-10$ & 2.21 & 14.29 & 360.23 & 0.15 & 0.01 & {$[8]$} \\
\hline Delta(Nigeria) & $0-15$ & - & 29.7 & 412.5 & - & - & [9] \\
\hline Yarmouk-Wadi wala (Jordanie) & $0-5$ & 49.9 & 26.7 & 291.1 & 1.87 & 0.17 & {$[10]$} \\
\hline Ma'an (Jordanie) & $0-5$ & 44.9 & 18.1 & 138.1 & 2.48 & 0.33 & {$[11]$} \\
\hline Aswan - Maghagha (Egypte) & $0-10$ & 16.3 & 12.94 & 200.211 & 1.26 & 0.08 & {$[12]$} \\
\hline Itagunmodi (Nigeria) & $20-30$ & 55.3 & 26.4 & 505.1 & 2.09 & 0.11 & {$[13]$} \\
\hline Kerala (Inde) & $0-5$ & 170.4 & 547.3 & 117.2 & 0.31 & 1.45 & [17] \\
\hline Koweit & - & 18 & 15 & 385 & 1.20 & 0.05 & [14] \\
\hline Kalpakkam (Inde) & $0-5$ & 16 & 119 & 406 & 0.13 & 0.04 & {$[15]$} \\
\hline Karnataka (Inde) & $0-50$ & 9.62 & 29.82 & 207.06 & 0.32 & 0.05 & [16] \\
\hline Worldwide & - & 35 & 30 & 400 & 1.17 & 0.09 & {$[6]$} \\
\hline Sebba (Burkina) & $0-20$ & 59.80 & 33.81 & 277.81 & 1.77 & 0.22 & Present study \\
\hline
\end{tabular}


lower than that of Kerala in India [17]. The ${ }^{232}$ Th activity concentration is just below the value reported at Kerala and Karnataka and higher than those of the other localities. For the ${ }^{40} \mathrm{~K}$, the activity concentration in the study area is lower than the value of five reported activity concentrations. The activity concentration calculation of ${ }^{238} \mathrm{U},{ }^{232} \mathrm{Th}$ and ${ }^{40} \mathrm{~K}$ from soil samples collected in the northeastern area of Burkina Faso reveals that except the ${ }^{40} \mathrm{~K}$, activity concentrations of above radionuclides are well above that of the world average. This confirms the existence of some radiological anomalies. To know the impact of these anomalies on people health, the radiological hazards will be assess in the following lines.

\subsection{Radiological parameters}

The study area is a predominantly rural locality where farming and gold mining are the most practiced activities.
Mining boom phenomenon has caused the displacement of populations to these localities and sometimes children and women leave school and agriculture activities in favor of gold mining. These vulnerable people are permanently found in the pits and in contact with extracted soil dust which could contains a significant concentrations of radionuclides. The present study has shown that the locality has a relatively high concentration of ${ }^{238} \mathrm{U}$ and ${ }^{232} \mathrm{Th}$. Thus radiological risks were assessed by the calculation of radiological parameters which values were compared to authorized international standards and results are shown in Tables 4 and 5.

Radium equivalent $R a_{\text {eg }}$ calculated using the activity concentrations of ${ }^{238} \mathrm{U},{ }^{232} \mathrm{Th}$ and ${ }^{40} \mathrm{~K}$ of the study area varies from $62.87 \mathrm{~Bq} \cdot \mathrm{Kg}^{-1}$ to $189.47 \mathrm{~Bq} \cdot \mathrm{Kg}^{-1}$. The mean value of $R a_{e q}$ is $129.55 \mathrm{~Bq} \cdot \mathrm{Kg}^{-1}$, which is much less than threshold value of $370 \mathrm{~Bq} \cdot \mathrm{Kg}^{-1}$. Table 4 shows that the minimum value of the absorbed gamma dose rate $\left(D_{R}\right)$ is obtained equal to $29.5 \eta \mathrm{Gy} \cdot \mathrm{h}^{-1}$ at Tangarce, while the
Table 4 Radiation hazard indices of soil from the Northeastern Burkina Faso

\begin{tabular}{llllllll}
\hline Sample ID & $R a_{e q}\left(\mathrm{~Bq} \cdot \mathrm{Kg}^{-1}\right)$ & $D_{R}\left(n G y \cdot h^{-1}\right)$ & $\begin{array}{l}\text { AEDE } \\
\left(\mathrm{mSv} \cdot \mathrm{y}^{-1}\right.\end{array}$ & $H_{\text {in }}$ & $H_{e x}$ & ELCR & AGDE $\left(\mu \mathrm{Sv} \cdot \mathrm{y}^{-1}\right)$ \\
\hline NE1101 & 77.24 & 35.92 & 0.22 & 0.27 & 0.21 & $1.55 \mathrm{E}-04$ & 252.69 \\
NE2001 & 62.87 & 29.50 & 0.18 & 0.21 & 0.17 & $1.27 \mathrm{E}-04$ & 209.01 \\
NEX0201 & 160.83 & 72.61 & 0.45 & 0.67 & 0.43 & $3.13 \mathrm{E}-04$ & 496.15 \\
NEX0301 & 156.77 & 71.24 & 0.44 & 0.63 & 0.42 & $3.07 \mathrm{E}-04$ & 490.57 \\
NEX0501 & 75.94 & 35.11 & 0.22 & 0.28 & 0.21 & $1.51 \mathrm{E}-04$ & 245.59 \\
NEX0601 & 84.70 & 38.88 & 0.24 & 0.29 & 0.23 & $1.67 \mathrm{E}-04$ & 272.94 \\
NEX0901 & 185.90 & 84.96 & 0.52 & 0.79 & 0.50 & $3.66 \mathrm{E}-04$ & 582.69 \\
NEX1001 & 189.47 & 86.65 & 0.53 & 0.81 & 0.51 & $3.73 \mathrm{E}-04$ & 594.21 \\
NEX1101 & 165.94 & 76.12 & 0.47 & 0.70 & 0.45 & $3.28 \mathrm{E}-04$ & 523.57 \\
NEX1201 & 135.80 & 65.37 & 0.40 & 0.47 & 0.37 & $2.81 \mathrm{E}-04$ & 466.17 \\
Mean value & 129.55 & 59.64 & 0.37 & 0.51 & 0.35 & $2.57 \mathrm{E}-04$ & 413.36 \\
Worldwide & 370 & 84 & 0.48 & 1 & 1 & $2.90 \mathrm{E}-04$ & 1000 \\
\hline
\end{tabular}

Table 5 Radiation hazard indices measured worldwide

\begin{tabular}{lllllllll}
\hline Locality/Country & Depth $(\mathrm{cm})$ & $R a_{e q}\left(\mathrm{~Bq} \cdot \mathrm{Kg}^{-1}\right)$ & $D_{R}\left(n G y \cdot h^{-1}\right)$ & $\mathrm{AEDE}\left(\mathrm{mSv} \cdot \mathrm{y}^{-1}\right)$ & $H_{\text {in }}$ & $H_{e x}$ & ELCR $\left(\times 10^{-4}\right)$ & Reference \\
\hline Tamilnadu & $0-10$ & 102.56 & 86.95 & 0.1067 & 0.2872 & 0.2777 & 3.735 & {$[8]$} \\
Delta & $0-15$ & 98.5 & 54.6 & 0.07 & 0.4 & 0.3 & - & {$[9]$} \\
Yarmouk-W.W. & $0-5$ & 103.1 & 51.5 & 0.063 & 0.39 & 0.28 & - & - \\
Ma'an & $0-5$ & 94.21 & 37.15 & - & 0.41 & 0.25 & - & {$[10]$} \\
Jessore & $0-5$ & 161 & 77 & - & 0.57 & 0.44 & - & {$[11]$} \\
Itagunmodi & $20-30$ & 132.14 & 66.3 & 0.4397 & 0.51 & 0.36 & - & {$[18]$} \\
Kerala & $0-5$ & 961.8 & 414.1 & 0.5078 & - & 2.6 & 17 & {$[13]$} \\
Koweit & - & 68.5 & 33.16 & 0.04 & 0.23 & 0.19 & - & {$[17]$} \\
Karnataka & $0-50$ & 72.94 & 33.23 & 0.004 & - & 0.19 & - & {$[14]$} \\
Sebba & $0-20$ & 129.55 & 59.64 & 0.37 & 0.51 & 0.35 & 2.57 & {$[16]$} \\
Worldwide & - & 370 & 84 & 0.48 & 1 & 1 & 2.9 & Present study
\end{tabular}



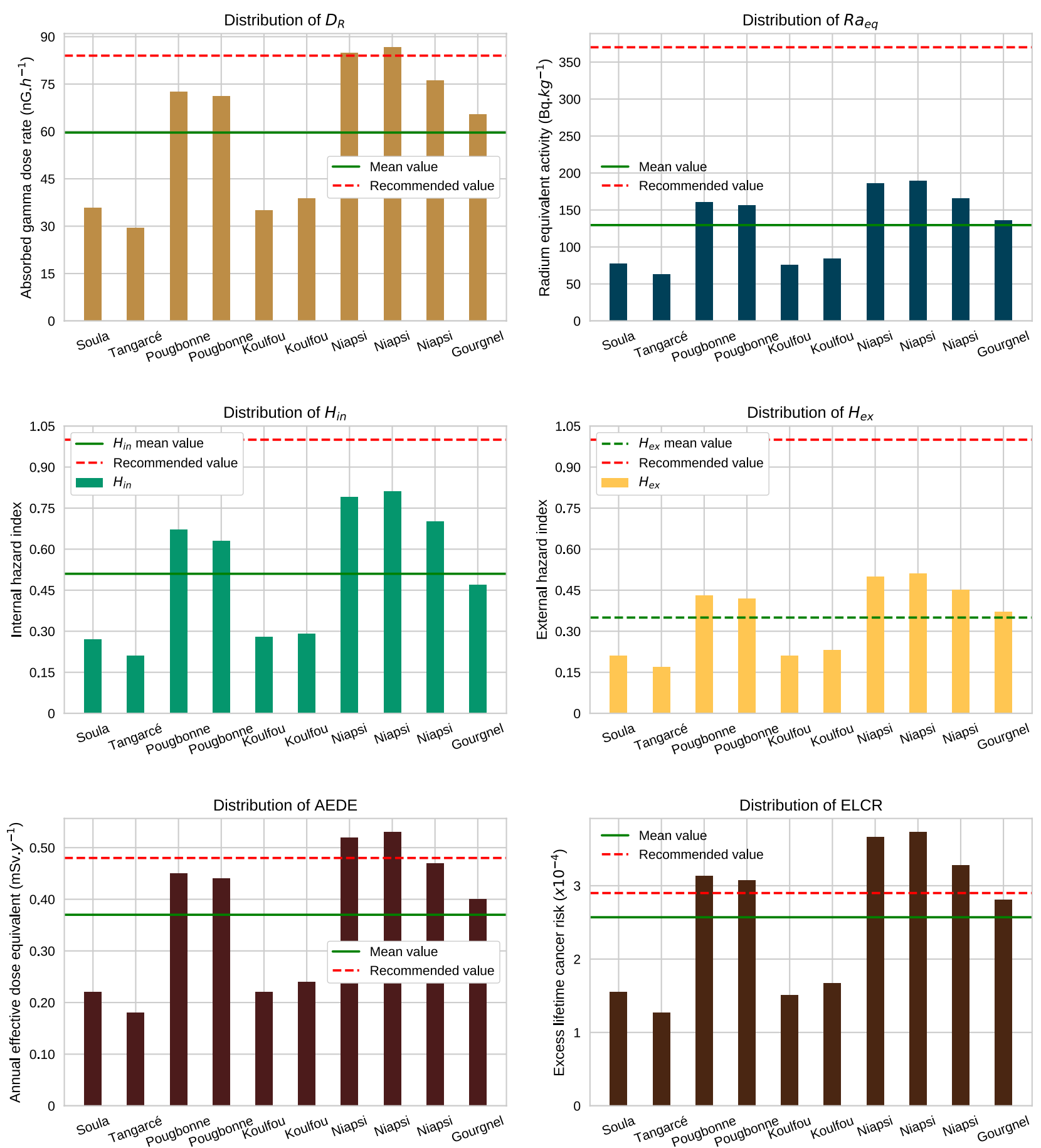

Fig. 3 Distribution of radiological parameters for a depth of $20 \mathrm{~cm}$

maximum value is found to be equal to $86.65 \eta \mathrm{Gy} \cdot \mathrm{h}^{-1}$ at Niapsi. The mean value of $D_{R}$ in the study area is $59.64 \eta \mathrm{Gy} \cdot \mathrm{h}^{-1}$, which is much less than the recommended maximum limit value of $84 \eta \mathrm{Gy} \cdot \mathrm{h}^{-1}$. Figure 3 shows that for Niapsi village, $D_{R}$ is a little higher than this maximum limit value. The values of annual effective dose equivalent (AEDE) ranged from $0.18 \mathrm{mSv} \cdot \mathrm{y}^{-1}$ to $0.53 \mathrm{mSv} \cdot \mathrm{y}^{-1}$ with a mean value of $0.37 \mathrm{mSv} \cdot \mathrm{y}^{-1}$, which is less than the recommended value of $0.8 \mathrm{mSv} \cdot \mathrm{y}^{-1}$ while its value at Niapsi is higher than the threshold one as it is shown on figure 3. The annual gonadal dose equivalent (AGDE) ranged from $209.01 \mu \mathrm{Sv} \cdot \mathrm{y}^{-1}$ to $594 \mu \mathrm{Sv} \cdot \mathrm{y}^{-1}$ and the mean value in the study area is $413.36 \mu \mathrm{Sv} \cdot \mathrm{y}^{-1}$, 
which is far lower than the recommended value of $1000 \mu \mathrm{Sv} \cdot \mathrm{y}^{-1}$. The external and internal hazard risks ranged from 0.17 to 0.51 and 0.21 to 0.81 respectively. These values are lower than the recommended value of unity. The values of excess lifetime cancer risk (ELCR) vary from $1.27 \times 10^{-4}$ to $3.73 \times 10^{-4}$ and Fig. 3 shows that the ELCR level is higher than the recommended value of $2.90 \times 10^{-4}$ in Poubonne and Niapsi villages.

The radiological risk assessment revealed that in the localities of Niapsi and Pougbonne, the value of the excess lifetime cancer risk (ELCR) is significantly higher than the recommended value. Ramasamy et al.[17] showed that in the locality of Kerala in India, the average ELCR value is six times that of the recommended value. In this locality there are at least 35, 000 new cases of cancer each year and between $70 \%$ and $90 \%$ of cancers are caused by environmental effects. It is therefore wise to give particular importance to this parameter and to pay attention on the naturally occurring radioactivity in Niapsi and Pougbonne.

\section{Conclusion}

The specific activity concentrations of ${ }^{238} \mathrm{U}$ and ${ }^{232} \mathrm{Th}$ obtained in the villages of Pougbonne and Niapsi are clearly higher than the world average. The ${ }^{238} \mathrm{U}$ concentration at Niapsi is three times higher than that of the world average, which could confirm the presence of uranium anomaly in the locality. Gourgnel is the only one locality in the study area where ${ }^{40} \mathrm{~K}$ concentration is much higher than the world average. The assessment of radiological hazard shows that, at Niapsi and sometimes at Pougbonne, the values of gamma dose rate $\left(D_{R}\right)$, annual effective dose equivalent (AEDE) and excess lifetime cancer risk (ELCR) are higher than the recommended maximum limit values. In the study area, it would be important to perform a study to see the evolution of the radiological parameters with the depth.

Acknowledgements The authors are thankful to the Director of National Authority of Radiation Protection and Nuclear Safety (ARSN) of Burkina Faso for granting the permission to use the facilities. They would also like to thank the International Atomic Energy Agency (IAEA) for providing sample for IAEA-TEL-2019 Proficiency Test.

Funding The authors have no relevant financial or non-financial interests to disclose. The authors have no competing interests to declare that are relevant to the content of this article. All authors certify that they have no affiliations with or involvement in any organization or entity with any financial interest or non-financial interest in the subject matter or materials discussed in this manuscript. The authors have no financial or proprietary interests in any material discussed in this article. The datasets generated during and/or analysed during the current study are available from the corresponding author on reasonable request.

\section{Declarations}

Conflict of interest On behalf of all authors, the corresponding author states that there is no conflict of interest.

Open Access This article is licensed under a Creative Commons Attribution 4.0 International License, which permits use, sharing, adaptation, distribution and reproduction in any medium or format, as long as you give appropriate credit to the original author(s) and the source, provide a link to the Creative Commons licence, and indicate if changes were made. The images or other third party material in this article are included in the article's Creative Commons licence, unless indicated otherwise in a credit line to the material. If material is not included in the article's Creative Commons licence and your intended use is not permitted by statutory regulation or exceeds the permitted use, you will need to obtain permission directly from the copyright holder. To view a copy of this licence, visit http://creativecommons. org/licenses/by/4.0/.

\section{References}

1. Bournas N, Ouedraogo A, Toure A, Prikhodko A, Plastow G, Mokubung K, Legault J, Wilson R (2007) Integrated interpretation of high-resolution airborne Geophysical survey of NorthEastern of Burkina Faso, J. Geophys., XXXVIII n ${ }^{\circ}$ 3 133-147

2. Beogo CE, Cisse Ol, Kanazoe AR, Maiga AR, Zougmore F (2019) Preliminary results measuring gamma dose rate distribution in North Eastern Burkina Faso where the concentration of uranium in the soil is elevated. Int J Appl Nat Sci IJANS 8:1-8

3. Beogo CE, Cisse OI, Kanazoe AR, Maiga AR, Zougmore F (2019) Preliminary study of gamma dose rate distribution in the anomaly of the west-central region of Burkina Faso: use of a portable gamma detector. Int J Res Appl Sci Eng Technol 7:1101-1106

4. Gilmore GR (2008) Practical gamma-ray spectrometry. Wiley, New York

5. Knoll GF (2000) Radiation detection and measurement. Wiley, New York

6. UNSCEAR (2000) Sources and Effects of Ionizing Radiation. Report to General Assembly, with Scientific Annexes. United Nations, New York

7. IRSN, Recommandation 2007 de la commission internationale de protection radiologique, ICRP, (2009)

8. Ravisanka R, Chandramohan J, Chandrasekaran A, Jebakumar JPP, Vijayalakshmi I, Vijayagopal P, Venkatraman B (2015) Assessments of radioactivity concentration of natural radionuclides and radiological hazards indices in sediment samples from the East Coast Tamilnadu. India Stat Approach Mar Pollut 97:419-430

9. Agbalagba EO, Avwiri GO, Chad-Umoreh YE (2012) Gamma spectroscopy measurement of natural radioactivity and assessment of radiation hazard indices in soil samples from oil fields environment of Delta state, Nigeria. J Environ Radioactiv 109:64-70

10. Al-Hamarneh IF, Awadallah MI (2009) Soil radioactivity levels and radiation hazard assessment in the highlands of northern Jordan. Radiat Meas 44:102-110

11. Saleh H, Shayeb MA (2014) Natural radioactivity distribution of southern part of Jordan (Ma'an) soil. Ann Nucl Energy 65:184-189

12. El-Gamal A, Nasr S, El-Taher A (2007) Study of the spatial distribution of natural radioactivity in the upper Egypt Nile River sediments. Radiat Meas 42:457-465 
13. Ademolo AK, Bello AK, Adejumobi AC (2014) Determination of natural radioactivity and hazard in soil samples in and around gold mining area in Itagunmodi. South-Western Nigeria. J Radiat Res Appl Sci 7:249-255

14. Alazemi N, Bajoga AD, Bradley DA, Regan PH, Shams H (2016) Soil radioactivity levels, radiological maps and risk assessment for the state of Kowait. Chemosphere 154:55-64

15. Kannan V, Rajan MP, lyengar MAR, Ramesh R (2002) Distribution of natural and anthropogenic radionuclides in soil and beach sand samples of Kalpakkam (India) using hyper pure germanium gamma ray spectrometry. Appl Radiat Tsotopes 57:109-119

16. Chandrashekara MS, Nagaraju KM, Pruthvi RKS, Paramesh L (2014) Natural radionuclides in soil samples and radiation dose to the population of Chamarajanaga district. Karnataka State, India. Int J Adv Sci Technol Res 4:466-474
17. Ramasamy V, Sundarrajan M, Paramasivam K, Meenakshisundaram V, Suresh G (2013) Assessment of spatial distribution and radiological hazardous nature of radionuclides in high background radiation area. Kerala, India. Appl Radiat Isotopes 73:21-31

18. Kabir KA, Islam SMA, Rahman MM (2009) Distribution of radionuclides in surface soil and bottom sediment in the district of Jessore. Bangladesh and evaluation of radiation hazard. J Bangladesh Acad Sci 33:117-130

Publisher's Note Springer Nature remains neutral with regard to jurisdictional claims in published maps and institutional affiliations. 